\title{
The effects of regular vigorous- and moderate-intensity aerobic exercise on senum BDNF level, aging- and lifestyle disease-related blood components in middle-aged women
}

\author{
Jae-Myun Ko ${ }^{1}$, Ji-Young Ahn², \& Jin-Seok Lee ${ }^{3 *}$ \\ ${ }^{1}$ Yonsei University, ${ }^{2}$ Korea University \& ${ }^{3}$ Korea Institute of Sports Science
}

\begin{abstract}
[Purpose] The purpose of this study was to investigate the effects of regular vigorous- and moderate-intensity aerobic exercise on serum brain-derived neurotrophic factor (BDNF) level, aging- and lifestyle disease-related blood components in middle-aged women. [Methods] The participants were recruited from a total of 19 physically healthy people aged 50-59 years, and were randomly divided into vigorous-intensity aerobic exercise (VIAE, $\mathrm{n}=10)$ and moderate-intensity aerobic exercise $(\mathrm{MIAE}, \mathrm{n}=9$ ) group. The participants were performed vigorous- and moderate-intensity aerobic exercise three times a week for eight weeks, and body composition measurement, graded exercise test, blood collection were performed before and after. [Results] Mean exercise time was significantly longer in the MIAE group than in the VIAE group. The $\mathrm{VO}_{2}$ max was significantly higher in the VIAE group than in the MIAE group. Body weight, BMI, and body fat percentage were significantly lower than pre both groups. The BDNF concentration was significantly higher in the VIAE group than in the MIAE group. The dehydroepiandrosterone sulfate (DHEA-s) and insulin-like growth factor-1 (IGF-1) concentration were significantly higher than pre both groups. The free fatty acid and triglyceride concentrations were significantly lower than pre both groups, and HDL-C concentrations were significantly higher than pre both groups. [Conclusion] Vigorous-intensity aerobic exercise not only increases maximal oxygen uptake and blood BDNF level in middle-aged women, but also induces positive changes in aging-related hormones and lifestyle-related blood variables.
\end{abstract}

Key Words: Aerobic exercise, BDNF, Aging-Related Hormone, Lifestyle-Related Disease

\begin{abstract}
서 론
최근 통계청에서 발표한 자료에 의하면, 65 세 이상 인 구 비율은 2030년 25\%, 2040년 33.9\%로 증가하리라 전망하고 있다(Korea statistics, 2019). 이러한 전망 속
\end{abstract}

논문 투고일 : 2019. 08. 30.

논문 수정일 : 2019. 10. 02.

게재 확정일 : 2019. 12. 27.

* 교신저자 : 이진석(js0420@kspo.or.kr).
에 고령화 문제는 우리나라뿐만 아니라 전 세계적인 문제 로 대두되고 있으며, 이를 해결하기 위한 개인적·사회적 관심이 높아지고 있다.

인간은 노년이 되면 신체적·생리적 기능의 현저한 감퇴 를 경험한다. 노년기 노화에 따라 신체 활동량 감소 및 운 동기능 저하, 균형 장애 등으로 점차 원활한 일상생활을 제한할 뿐만 아니라 DHEA-s(Dehydroepiandrosterone sulfate)와 Insulin-like Growth Factor 1( $\mathrm{IGF}-1)$ 과 같 은 특정 호르몬 감소가 두드러진다(Gauchard et al., 
2003). DHEA-s는 20대에 최고 농도에 도달하고 30대 부터 점차 감소하여 생활습관병 발병 증가에 기인하는 것 으로 알려져 있다(McArdle et al., 2010; Thoms et al., 1994). 또한, 성장호르몬 감소에 의해 영향을 받는 IGF-1은 일주기 변화가 큰 성장호르몬과 달리 일주기 변 화가 거의 없는 이유로 동화작용 호르몬의 유용한 지표로 활용된다(Corpas, Harman, \& Blackman, 1993). 노 년기에는 DHEA-s, 성장호르몬 결핍과 함께 기억력 감퇴 가 두드러지는데 이는 노화 관련 호르몬과 인지기능의 관 련에 관하여 연구한 선행연구를 토대로 추측할 수 있다. 선행연구에서는 25 명의 건강한 노인을 대상으로 $\mathrm{IGF}-1$ 과 인지기능의 일부 요인 간 연관성이 높다고 보고한 바 있다(Aleman et al., 1999). McCusker et al. (2006) 은 뇌에서 $\mathrm{IGF}-1$ 과 brain-derived neurotrophic factor (BDNF)가 신경세포 생존과 가소성을 향상하기 위 해 활동하며, $\mathrm{IGF}-1$ 증가에 의해 $\mathrm{BDNF}$ 도 증가한다고 보고한 바 있다. $\mathrm{BDNF}$ 는 학습과 기억에 중요한 역할을 하는 뇌세포 생성 인자로 알려져 있으며(Aguiar et al., 2011; Araki et al., 2014; Corripio et al., 2012; Cowansage et al., 2010), 신경조직 외 골격근 등에도 발현된다고 보고된 바 있다(Matthews et al., 2009). 선 행연구를 종합하면, 노화에 따라 신체적·생리적 기능 감 퇴와 함께 노화 관련 호르몬 및 $\mathrm{BDNF}$ 농도 저하가 두드 러지며, 이는 생활습관발병과도 연관이 있음을 추론할 수 있다. 노년기 건강한 삶을 영위하기 위해서는 중년기부터 예방 차원에서의 건강관리가 무엇보다도 중요하며, 필연 적으로 폐경이라는 신체적·생리적 변화를 경험하는 여성 의 건강관리는 시급한 실정이다.

미국스포츠의학회에 의하면, 중년 여성의 건강 유지 및 증진을 위해서는 규칙적으로 중등강도 유산소성 운동을 권장하고 있다(ACSM, 2018). 선행연구들에서는 규칙 적인 유산소성 운동이 원활한 혈액 순환과 산소 공급을 통해 뇌 기능 향상과 기억력을 담당하는 해마 손상을 감 소시켜 $\mathrm{DHEA}^{-\mathrm{S}}$ 농도를 증가한다고 보고한 바 있다 (Colcombe et al., 2003; Dimeo et al., 2001). 아울러, 규칙적인 운동은 중성지방을 분해하는 지단백 분해 효소를 활성화하여 지방의 에너지 이용률을 향상하고 혈중 지질 성 분을 감소함으로써 DHEA-s 농도를 증가한다(Bergeron et al., 2001). Walsh et al. (2015)는 유산소성 운동이
$\mathrm{IGF}-1$ 과 $\mathrm{BDNF}$ 증가에 효과적이며, 중등강도 이상 신체 활동은 $\mathrm{BDNF}$ 의 긍정적인 변화를 야기함은 물론 (Ferris, Williams, \& Shen, 2007), 선행연구들에서는 $\mathrm{BDNF}$ 증가가 혈당, 유리지방산, 총콜레스테롤과 같은 생활습관병 관련 혈액 변인의 개선과 밀접한 관련이 있다 고 보고한 바 있다(Tsuchida et al., 2002; Tsuchida et al., 2001). 이처럼 선행연구를 토대로 규칙적인 유산소 성 운동은 $\mathrm{BDNF}$ 농도, 노화 및 생활습관병 관련 혈액 변 인 개선에 긍정적인 영향을 미칠 것으로 생각되지만, 그 강도와 관련하여서는 논쟁의 여지가 있다.

몇몇 선행연구에서는 중등강도와 비교하여 고강도 유산 소성 운동이 $\mathrm{BDNF}$ 농도를 더욱 증가하고(Afzalpour et al., 2015; Jeon \& Ha, 2017; TaheriChadorneshin et al., 2017, Vega et al., 2006), 다른 선행연구에서는 12 주간 노인 여성에게 최대심박수 $60 \%$ 강도로 유산소성 운 동만 하는 것보다 저항성 운동을 포함하는 복합운동 방법 이 DHEA-s 농도를 증가시켰다고 보고한 바 있기 때문이 다(Ha \& Son, 2018). 또한, 다른 선행연구에서는 BDNF 농도의 긍정적인 변화를 위해 신체활동을 통한 에너지소비 량 증가와 $\leq 60 \% \mathrm{HRR}$ 운동을 해야 한다고 주장한 바 있다 (Angelucci et al., 2016; Mackay et al., 2017).

이렇듯, 유산소성 운동은 일반적으로 혈중 $\mathrm{BDNF}$ 농 도, 노화 및 생활습관병 관련 혈액 변인에 긍정적인 영향 을 미칠 수 있음에도 불구하고 운동이 필요한 특정 집단이 라 볼 수 있는 중년 여성을 대상으로 혈중 $\mathrm{BDNF}$ 농도, 노 화 및 생활습관병 관련 혈액 변인을 모두 함께 확인하고 검증한 연구는 다소 미흡한 실정이다. 게다가 운동 강도 차이에 관하여 검증한 연구들은 대부분 운동량을 고려하 지 않고 규명한 탓에 운동 강도보다 운동량 차이에 기인한 결과를 제시하는 데 제한점이 존재할 수 있을 것이라 판단 된다. 이에 운동량을 정량화시키고 운동강도를 각각 설정 한 후 운동을 실시한다면 이는 강도 차이에 따른 생리학적 변인들의 차이가 보다 명확하게 입증 될 것으로 사료 된다.

따라서 본 연구의 목적은 고강도와 중등강도 유산소성 운동의 강도 차이를 고려하여 운동량을 동일화하고 8주 간 고강도와 중등강도 유산소성 운동이 중년 여성의 혈중 $\mathrm{BDNF}$ 농도, 노화 및 생활습관병 관련 혈액 변인에 미치 는 영향을 검증함으로써 중년 여성의 건강 유지 및 증진 을 위한 기초자료를 제공하는 데 있다. 


\section{연구방법}

\section{연구대상}

연구대상자는 50-59세의 신체적으로 건강한 총 19명 을 대상으로 모집하였다. 연구대상자의 제외 기준은 심혈 관계 및 근골격계 질환을 포함하는 의학적 질환이 있는 자이며 또한, 본 프로그램에서 제 공하는 유산소성 운동을 제외한 다른 운동 프로그램에 참여할 예정이거나 지난 6 개월간 규칙적인 운동을 지속한 자는 제외하였다.

연구대상자 모집 시 여성이라는 특성상 월경 기간이 실험 결과에 영향을 미칠 수 있다는 선행연구에 따라 (Bisdee et al., 1989) 폐경 유무와 월경 일정을 확인한 후 채혈 등 실험 일정을 조율하였다. 모든 연구대상자에 게는 연구 목적 및 절차를 충분히 설명하였으며, 연구 기 간 중 실험 결과에 대해 영향을 줄 수 있는 음주, 흡연, 약 물 복용 등을 금하도록 교육하였다. 연구대상자들은 고강 도 유산소성 운동 그룹(Vigorous-Intensive Aerobic Exercise; VIAE, $n=10$ ), 중등강도 유산소성 운동 그룹 (Moderate-Intensive Aerobic Exercise; MIAE, $\mathrm{n}=9$ )으로 무작위로 분류하였으며, 연구대상자들의 신체 적 특성은 〈Table 1〉에 제시한 바와 같다.

Table 1. Physical characteristics of participants (Mean \pm SD)

\begin{tabular}{cccc}
\hline \hline Variables & $\begin{array}{c}\text { Age } \\
\text { (years })\end{array}$ & $\begin{array}{c}\text { Height } \\
(\mathrm{cm})\end{array}$ & $\begin{array}{c}\text { Weight } \\
(\mathrm{kg})\end{array}$ \\
\hline VIAE $(\mathrm{n}=10)$ & $54.70 \pm 2.90$ & $160.67 \pm 3.37$ & $63.64 \pm 4.05$ \\
\hline MIAE $(\mathrm{n}=9)$ & $53.88 \pm 2.31$ & $159.68 \pm 1.72$ & $63.14 \pm 4.44$ \\
\hline
\end{tabular}

VIAE: vigorous-intensive aerobic exercise, MIAE: moderate-intensive aerobic exercise.

\section{연구 설계 및 절차}

모든 연구대상자는 사전·사후 실험을 위해 각 실험 전 날 과도한 신체활동을 금하고 12 시간 공복을 유지하였 다. 실험 당일에는 무선심박측정기 $(\mathrm{FT} 2$, Polar, Finland)를 이용하여 안정시 심박수 $(80 \mathrm{bpm} / \mathrm{min}$ 이하 $)$ 에 도달하였을 때 채혈하도록 하였다. 그리고 본 운동 전 운동부하검사를 통해 $\mathrm{VO}_{2} \max$ 를 산출하고 공식에 의해
두 운동 그룹 간 운동량 $(\mathrm{kcal})$ 을 동일화하였으며, 8주간 주 3회 격렬한 강도 및 중등강도 유산소성 운동을 각각 실시하였다.

\section{유산소성 운동 프로토콜}

본 연구에서 유산소성 운동은 트레드밀을 이용하여 8 주간 주 3회 실시하였다. 최근 $\operatorname{ACSM}(2018)$ 에 의하면 성인 대상 운동 프로그램의 대부분 목표 운동량은 주당 $1,000 \mathrm{Kcal}$ 의 에너지 소모량과 함께 주당 약 150 분 정도 수준을 제시하고 있다(ACSM, 2018). 이에 본 연구에서 는 운동부하검사를 통한 $\mathrm{VO}_{2} \max$ 를 기준으로 $\mathrm{VIAE}$ 그 룹은 $\mathrm{VO}_{2} \max$ 의 $75-80 \%$ 강도에 해당하는 $\mathrm{METs}$ 값을 적용하여(Norton et al., 2010), 주당 $1,000 \mathrm{Kcal}$ 가 소 비되도록 계산하였고 트레드밀 운동 속도는 약 8.5 $\mathrm{METs}$ 강도에 해당하는 $5.2 \mathrm{mph}$ 을 설정·적용하였다. $\mathrm{MIAE}$ 그룹은 $\mathrm{VO}_{2} \max$ 약 55-60\% 강도에 해당하는 METs 값을 적용하여(Norton et al., 2010), 주당 $1,000 \mathrm{Kcal}$ 가 소비되도록 계산하였고 트레드밀 운동 속 도는 Ainsworth(2000)의 Compendium of Physical Activities에서 제시한 METs별 달리기 속도를 참고하여 약 $6 \mathrm{METs}$ 에 강도에 해당하는 $4 \mathrm{mph}$ 을 설정·적용하였다. 단, 본 연구에서는 METs 강도를 토대로 집단의 운동량을 동일화하고자 하였으나 개인별 운동강도를 고려하지 못한 제한점이 있다. 두 그룹에 대한 에너지소비량 계산 방법은 〈Table 2〉에 제시한 바와 같다.

Table 2. Calculation of METs, MET-Min ${ }^{-1}$, and $\mathrm{Kcal} \cdot \mathrm{Min}^{-1}$

$0.0175 \mathrm{kcal} \cdot \mathrm{kg}^{-1} \cdot \mathrm{min}^{-1} \cdot \mathrm{MET}^{-1} \times \mathrm{METs} \times$ Weight $(\mathrm{kg})$ $=\mathrm{kcal} / \mathrm{min}$

$\operatorname{ACSM}(2018)$

\section{측정 항목 및 방법}

\section{신체계측 및 신체구성}

신체계측 및 신체구성은 자동신체계측기(Fanics, $\mathrm{FE} 810$, Korea)를 이용하여 측정하였고 체중 및 체지방 률 $(\%)$ 측정은 생체전기저항법에 의해 측정되는 신체구 성측정기(Inbody 720, Biospace, Korea)를 이용하여 
측정하였다. 연구대상자는 측정 12 시간 전에는 물 이외 어떠한 음료나 음식물 섭취를 금하도록 하였고 측정 직전 배변 및 배뇨하도록 하였다. 또한, 측정 시 인체에서 금속 류를 모두 제거한 후 측정하도록 하였다.

\section{운동부하검사}

운동부하검사는 신체계측 및 신체구성 측정 후 10 분 이상 휴식을 취한 후 심박수가 안정시 수준에 도달하였을 때 하였다. 트레드밀 (TM65 Treadmill, Quinton, USA) 을 이용하여 무선심박수측정기 (FT2, Polar, Finland)를 착용한 상태로 운동부하검사를 하였고 연구대상자가 중 년 여성임을 고려하여 안전한 측정을 위해 Modified Bruce Protocol을 적용하였다(Franks et al., 1998). 그 리고 Metabolic Measurement System (TrueOne 2400, ParvoMedics, USA)를 사용하여 최대산소섭취량 $\left(\mathrm{VO}_{2} \max \right)$ 을 산출하였다.

\section{혈액 채취 및 분석}

본 연구에서는 유산소성 운동 사전·사후 안정시 각각 총 2 회 혈액 샘플을 채취하였다. 혈액 샘플 채취 시에는 무선심박수측정기(FT2, Polar, Finland)를 통해 안정시 심박수를 확인한 후 안정시 심박수에 도달했을 때 임상병 리사가 채취하였다. 항응고 처리된 Vacutainer Tube와 22-Gage Needle을 이용하여 상완주정맥 (Antecubital Vein)에서 혈액 약 $7 \mathrm{~mL}$ 를 채취하였으며, 채취된 혈액은 30 분 이상 상온에서 보관 후 원심분리기를 이용하여 $3000 \mathrm{rpm}$ 의 속도로 15 분간 원심분리하였다. 혈장과 혈 청을 분리하여 분석 시까지 $-20^{\circ} \mathrm{C}$ 에서 냉동 보관하였으 며, 혈액분석 업체에 의뢰하여 분석하였다.

$\mathrm{BDNF}$ 는 Molecular device(U.S.A)를 사용하여 표준 화된 ELISA(Enzyme-Linked Immunosobent Assay) 방 법으로 분석하였다. IGF-1은 Immulite 2000(Siemens, USA) 검사 장비로 CLIA(Chemiluminescence immunoassay) 방법을 통해 IGF-1(Siemens, USA) 시약을 사용하여, 분석하였다. DHEA-s는 radioactive I125 labeled DHEA-S 04 를 $1.0 \mathrm{~mL}$ 넣고 Mixing 후 $37^{\circ} \mathrm{C}$ water bath에서 30분 동안 배양하였으며, Diagnostic products Co, Coat-acount DHEA-sulfate 시약을 사용하여, 분석하였다. 글 루코스는 Modular Analytics(PE, Roche, Germany)를
사용하여, GLU(Roche, Germany) kit를 사용하여 Enzymatic Kinetic Assay(Hexokinase) 검사 방법으 로 분석하였다. 유리지방산은 Modular Analytics 장비 (PE, Roche, Germany)로 NEFA HR.II(Wako, Japan) Kit를 이용하여, Colorimetry, Enzymatic assay 방법으로 분석하였다. 중성지방, 고밀도지단백콜레스테 롤, 저밀도지단백콜레스테롤은 Modular Analytics $(\mathrm{PE}$, Roche, Germany)로 Enzymatic Colorimetric Assay 방법을 통해 분석하였다.

\section{통계 처리}

모든 데이터는 SPSS PC+ for Windows(version 23.0) 통계 프로그램을 이용하여 종속 변인들의 평균 $(\mathrm{M})$ 과 표준편차 $(\mathrm{SD})$ 를 산출하였다. 고강도와 중등강도 유산소성 운동 그룹에 대한 평균 운동 시간 차이를 알아 보기 위해 독립 t-test를 하였으며, 고강도와 중등강도 유 산소성 운동 그룹에 의한 $\mathrm{BDNF}$ 농도, 노화 관련 호르몬, 생활습관병 관련 혈액 변인에 대한 영향을 검증하기 위해 이원변량분석 (Two-way ANOVA)을 하였다(그룹(2)×시 점 (2)). 유의 수준은 $\alpha=.05$ 였다.

\section{연구결과}

\section{유산소성 운동 그룹 간 평균 운동 시간 차이}

VIAE와 MIAE 그룹 간 평균 운동 시간 차이는 〈Table $3\rangle$ 에 제시한 바와 같다. 평균 운동 시간은 VIAE 그룹의 경우, $40.30 \pm 3.71$ 분, $\mathrm{MIAE}$ 그룹의 경우, $59.22 \pm$ 3.99분으로 MIAE 그룹이 VIAE 그룹보다 유의하게 길 었다 $(p<.05)$ (Table 3).

Table 3. Average exercise time

$(\mathrm{Mean} \pm \mathrm{SD})$

\begin{tabular}{lcccc}
\hline \hline Variables & $\operatorname{VIAE}(\mathrm{n}=10)$ & $\operatorname{MIAE}(\mathrm{n}=9)$ & $\mathrm{t}$ & $p$ \\
\hline $\begin{array}{c}\text { Exercise } \\
\text { Time }\end{array}$ & $40.30 \pm 3.71$ & $59.22 \pm 3.99$ & 10.704 & $.001^{*}$ \\
\hline \hline
\end{tabular}

VIAE: vigorous-intensive aerobic exercise, MIAE: moderate- intensive aerobic exercise.

${ }^{*} p<.05$ 


\section{유산소성수행능력의 변화}

규칙적인 고강도 및 중등강도 유산소성 운동에 따른 유산소성수행능력의 변화는 다음 〈Table 4〉에 제시한 바 와 같다. 최대산소섭취량은 $\mathrm{VIAE}$ 그룹의 경우 사전 $29.8 \mathrm{ml} / \mathrm{kg} / \mathrm{min}$ 에서 사후 $35.2 \mathrm{ml} / \mathrm{kg} / \mathrm{min}$ 로, $\mathrm{MAE}$ 그룹의 경우, 사전 $32 \mathrm{ml} / \mathrm{kg} / \mathrm{min}$ 에서 사후 $33.3 \mathrm{ml} / \mathrm{kg} / \mathrm{min}$ 로 그룹과 시점 간 상호작용 효과가 나타났다 $(\mathrm{F}=6.058$, $p=.019)$. 주효과 분석 결과, 그룹에서 유의한 차이가 나 타나지 않았으나 $(\mathrm{F}=.047, p=.830)$, 시점에서는 유의 한 차이가 나타났다 $(\mathrm{F}=16.901, p=.001)$ (Table 4).

Table 4. Change of $\mathrm{VO}_{2} \max$

$(\mathrm{Mean} \pm \mathrm{SD})$

\begin{tabular}{ccccccc}
\hline \hline Variables & Group & $\mathrm{N}$ & Pre & Post & Sig. & $p$ \\
\hline & VIAE & 10 & $\begin{array}{c}29.8 \\
\pm 1.25\end{array}$ & $\begin{array}{c}35.2 \\
\pm 1.94\end{array}$ & Group & .830 \\
$\begin{array}{c}\mathrm{VO}_{2} \mathrm{max} \\
(\mathrm{mL} / \mathrm{kg} / \mathrm{min})\end{array}$ & & & & & Time & $.001^{*}$ \\
& MIAE & 9 & $\begin{array}{c}32.0 \\
\pm 3.08\end{array}$ & $\begin{array}{c}33.3 \\
\pm 3.40\end{array}$ & $\begin{array}{c}\text { Group } \\
\times \text { Time }\end{array}$ & $.019^{*}$ \\
\hline \hline
\end{tabular}

VIAE: vigorous-intensive aerobic exercise, MIAE: moderate-intensive aerobic exercise.

${ }^{*} p<.05$

\section{신체구성의 변화}

규칙적인 고강도 및 중등강도 유산소성 운동에 따른 신체구성의 변화는 〈Table 5>에 제시한 바와 같다. 체중 은 그룹과 시점 간 상호작용 효과가 나타나지 않았으며 $(\mathrm{F}=065, p=.800)$, 주효과 분석 결과, 그룹에서 유의한 차이가 나타나지 않았고 $(\mathrm{F}=.015, p=.904)$, 시점에서 는 유의한 차이가 나타났다 $(\mathrm{F}=5.650, p=.023) . \mathrm{BMI}$ 는 그룹과 시점 간 상호작용 효과가 나타나지 않았으며 $(\mathrm{F}=.081, p=.778)$, 주효과 분석 결과, 그룹에서 유의 한 차이가 나타나지 않았고 $(\mathrm{F}=.350, p=.558)$, 시점에 서 유의한 차이가 나타났다 $(\mathrm{F}=6.903, p=.013)$. 체지방 률은 그룹과 시점 간 상호작용 효과가 나타나지 않았으며 $(\mathrm{F}=.297, p=.589)$, 주효과 분석 결과, 그룹과 시점에 서 각각 유의한 차이가 나타났다(각각 $\mathrm{F}=4.114$, $p=.050 ; \mathrm{F}=8.271, p=.007)$ (Table 5).
Table 5. Change of body composition

$(\mathrm{Mean} \pm \mathrm{SD})$

\begin{tabular}{|c|c|c|c|c|c|c|}
\hline Variables & Group & $\mathrm{N}$ & Pre & Post & Sig. & $p$ \\
\hline \multirow{3}{*}{$\begin{array}{l}\text { Body } \\
\text { Weight } \\
\text { (kg) }\end{array}$} & \multirow[t]{2}{*}{ VIAE } & \multirow[t]{2}{*}{10} & \multirow{2}{*}{$\begin{array}{c}63.64 \\
\pm 4.05\end{array}$} & \multirow{2}{*}{$\begin{array}{r}60.18 \\
\pm 4.08\end{array}$} & Group & .904 \\
\hline & & & & & Time & $.023 *$ \\
\hline & MIAE & 9 & $\begin{array}{c}63.14 \\
\pm 4.44\end{array}$ & $\begin{array}{r}60.35 \\
\pm 3.53\end{array}$ & $\begin{array}{l}\text { Group } \\
\times \text { Time }\end{array}$ & .800 \\
\hline \multirow{3}{*}{$\begin{array}{c}\mathrm{BMI} \\
\left(\mathrm{kg} / \mathrm{m}^{2}\right)\end{array}$} & \multirow[t]{2}{*}{ VIAE } & \multirow[t]{2}{*}{10} & \multirow{2}{*}{$\begin{array}{l}24.63 \\
\pm 1.05\end{array}$} & \multirow{2}{*}{$\begin{array}{l}23.27 \\
\pm 1.09\end{array}$} & Group & .558 \\
\hline & & & & & Time & $.013 *$ \\
\hline & MIAE & 9 & $\begin{array}{l}24.77 \\
\pm 1.92\end{array}$ & $\begin{array}{l}23.68 \\
\pm 1.57\end{array}$ & $\begin{array}{l}\text { Group } \\
\times \text { Time }\end{array}$ & .778 \\
\hline \multirow{3}{*}{$\begin{array}{c}\text { Body Fat } \\
(\%)\end{array}$} & \multirow[t]{2}{*}{ VIAE } & \multirow[t]{2}{*}{10} & \multirow{2}{*}{$\begin{array}{l}30.10 \\
\pm 2.48\end{array}$} & \multirow{2}{*}{$\begin{array}{l}27.05 \\
\pm 2.67\end{array}$} & Group & $.050 *$ \\
\hline & & & & & Time & $.007^{*}$ \\
\hline & MIAE & 9 & $\begin{array}{c}31.42 \\
\pm 2.98\end{array}$ & $\begin{array}{c}29.34 \\
\pm 2.84\end{array}$ & $\begin{array}{l}\text { Group } \\
\times \text { Time }\end{array}$ & .589 \\
\hline
\end{tabular}

VIAE: vigorous-intensive aerobic exercise, MIAE: moderate-intensive aerobic exercise, BMI: body mass index.

${ }^{*} p<.05$

\section{혈중 BDNF 및 노화 관련 호르몬 농도의 변화}

규칙적인 고강도 및 중등강도 유산소성 운동에 따른 혈중 $\mathrm{BDNF}$ 농도와 노화 관련 호르몬 농도 변화는 〈Table 6〉에 제시한 바와 같다. 혈중 BDNF 농도는 그룹 과 시점 간 상호작용 효과가 나타났으며 $(\mathrm{F}=6.028$, $p=.019)$, 주효과 분석 결과, 그룹에서 유의한 차이가 나 타나지 않았으나 $(\mathrm{F}=.106, p=.747)$, 시점에서 유의한 차이가 나타났다 $(\mathrm{F}=12.442, p=.001) . \mathrm{DHEA}^{-\mathrm{S}}$ 농도 는 그룹과 시점 간 상호작용 효과가 나타나지 않았으며 $(\mathrm{F}=.906, p=.348)$, 주효과 분석 결과, 그룹에서 유의한 차이가 나타나지 않았으나 $(\mathrm{F}=.880, p=.355)$, 시점에서 는 유의한 차이가 나타났다 $(\mathrm{F}=6.092, p=.019) . \mathrm{IGF}-1$ 농도는 그룹과 시점 간 상호작용 효과가 나타나지 않았으며 $(\mathrm{F}=.904, p=.348)$, 주효과 분석 결과, 그룹과 시점에서 각각 유의한 차이가 나타났다(각각 $\mathrm{F}=8.385, p=.007$; $\mathrm{F}=7.381, p=.010)($ Table 6$)$.

\section{생활습관병 관련 혈액 변인의 변화}

규칙적인 고강도 및 중등강도 유산소성 운동에 따른 생활습관병 관련 혈액 변인의 변화는 〈Table 7〉에 제시 한 바와 같다. 글루코스 농도는 그룹과 시점 간 상호작용 
Table 6. Change of BDNF levels and Aging-Related Hormones

$(\mathrm{Mean} \pm \mathrm{SD})$

\begin{tabular}{|c|c|c|c|c|c|c|}
\hline Variables & Group & $\mathrm{N}$ & Pre & Post & Sig. & $p$ \\
\hline \multirow{3}{*}{$\begin{array}{l}\text { BDNF } \\
(\mathrm{pg} / \mathrm{mL})\end{array}$} & \multirow[t]{2}{*}{ VIAE } & \multirow[t]{2}{*}{10} & \multirow[t]{2}{*}{$\begin{array}{c}22492.31 \\
\pm 1795.09\end{array}$} & \multirow[t]{2}{*}{$\begin{array}{c}26396.47 \\
\pm 1808.66\end{array}$} & Group & .747 \\
\hline & & & & & Time & $.001^{*}$ \\
\hline & MIAE & 9 & $\begin{array}{c}24306.97 \\
\pm 1880.58\end{array}$ & $\begin{array}{l}25006.66 \\
\pm 2511.17\end{array}$ & $\begin{array}{l}\text { Group } \\
\times \text { Time }\end{array}$ & $.019^{*}$ \\
\hline \multirow{3}{*}{$\begin{array}{l}\text { DHEA-s } \\
\text { (ug/dL) }\end{array}$} & \multirow[t]{2}{*}{ VIAE } & \multirow[t]{2}{*}{10} & \multirow[t]{2}{*}{$\begin{array}{l}160.80 \\
\pm 6.46\end{array}$} & \multirow[t]{2}{*}{$\begin{array}{l}183.10 \\
\pm 14.0\end{array}$} & Group & .355 \\
\hline & & & & & Time & $.019 *$ \\
\hline & MIAE & 9 & $\begin{array}{c}160.89 \\
\pm 3.40\end{array}$ & $\begin{array}{l}170.78 \\
\pm 37.8\end{array}$ & $\begin{array}{l}\text { Group } \\
\times \text { Time }\end{array}$ & .348 \\
\hline \multirow{3}{*}{$\begin{array}{c}\text { IGF-1 } \\
\text { (ng/mL) }\end{array}$} & \multirow[t]{2}{*}{ VIAE } & \multirow[t]{2}{*}{10} & \multirow[t]{2}{*}{$\begin{array}{l}185.40 \\
\pm 12.25\end{array}$} & \multirow[t]{2}{*}{$\begin{array}{c}212.49 \\
\pm 33.26\end{array}$} & Group & $.007 * *$ \\
\hline & & & & & Time & $.010^{*}$ \\
\hline & MIAE & 9 & $\begin{array}{l}171.03 \\
\pm 8.36\end{array}$ & $\begin{array}{l}184.07 \\
\pm 26.6\end{array}$ & $\begin{array}{l}\text { Group } \\
\times \text { Time }\end{array}$ & .348 \\
\hline
\end{tabular}

VIAE: vigorous-intensive aerobic exercise, MIAE: moderate-intensive aerobic exercise, BDNF: brain-derived neurotrophic factor, DHEA-s: dehydroepiandrosterone sulfate, IGF-1: Insulin-like growth factor-1. ${ }^{*} p<.05$

효과가 나타나지 않았으며 $(\mathrm{F}=.883, p=.354)$, 주효과 분석 결과, 그룹과 시점에서 모두 유의한 차이가 나타나 지 않았다(각 $\mathrm{F}=003, p=.956 ; \mathrm{F}=1.676, p=.204$ ). 유리지방산 농도는 그룹과 시점 간 상호작용 효과가 나타 나지 않았으며 $(\mathrm{F}=1.472, p=.233)$, 주효과 분석 결과, 그룹에서 유의한 차이가 나타나지 않았으나 $(\mathrm{F}=2.653$, $p=.113)$, 시점에서는 유의한 차이가 나타났다 $(\mathrm{F}=5.668, p=.023)$. 중성지방 농도는 그룹과 시점 간 상호작용 효과가 나타나지 않았으며 $(\mathrm{F}=.010$, $p=.992)$, 주효과 분석 결과, 그룹과 시점에서 모두 유의 한 차이가 나타났다(각 $\mathrm{F}=6.046, p=.019 ; \mathrm{F}=8.036$, $p=.008)$ (Table 7).

$\mathrm{HDL}-\mathrm{C}$ 농도는 그룹과 시점 간 상호작용 효과가 나타 나지 않았으며 $(\mathrm{F}=.082, p=.776)$, 주효과 분석 결과, 그룹에서 유의한 차이가 나타나지 않았으나 $(\mathrm{F}=3.119$, $p=.086)$, 시점에서는 유의한 차이가 나타났다 $(\mathrm{F}=6.291$, $p=.017) . \mathrm{LDL}-\mathrm{C}$ 농도는 그룹과 시점 간 상호작용 효과 가 나타나지 않았으며 $(\mathrm{F}=.650, p=.426)$, 주효과 분석
Table 7. Change of disease-related components (Mean \pm SD)

\begin{tabular}{|c|c|c|c|c|c|c|}
\hline Variables & Group & $\mathrm{N}$ & Pre & Post & Sig. & $p$ \\
\hline \multirow{3}{*}{$\begin{array}{l}\text { Glucose } \\
\text { (mg/dL) }\end{array}$} & \multirow{2}{*}{ VIAE } & \multirow{2}{*}{10} & \multirow{2}{*}{$\begin{array}{c}96.30 \\
\pm 15.81\end{array}$} & \multirow{2}{*}{$\begin{array}{c}87.90 \\
\pm 12.01\end{array}$} & Group & .956 \\
\hline & & & & & Time & .204 \\
\hline & $\begin{array}{c}\text { MIA } \\
\text { E }\end{array}$ & 9 & $\begin{array}{l}92.56 \\
\pm 6.26\end{array}$ & $\begin{array}{l}91.22 \\
\pm 9.28\end{array}$ & $\begin{array}{l}\text { Group } \\
\times \text { Time }\end{array}$ & .354 \\
\hline \multirow{3}{*}{$\begin{array}{c}\text { FFA } \\
(\mathrm{uEq} / \mathrm{L})\end{array}$} & \multirow{2}{*}{ VIAE } & \multirow{2}{*}{10} & \multirow{2}{*}{$\begin{array}{r}749.30 \\
\pm 23.45\end{array}$} & \multirow{2}{*}{$\begin{array}{c}658.54 \\
\pm 148.12\end{array}$} & Group & .113 \\
\hline & & & & & Time & $.023^{*}$ \\
\hline & $\begin{array}{c}\text { MIA } \\
\text { E }\end{array}$ & 9 & $\begin{array}{c}759.78 \\
\pm 11.69\end{array}$ & $\begin{array}{c}730.31 \\
\pm 15.39\end{array}$ & $\begin{array}{l}\text { Group } \\
\times \text { Time }\end{array}$ & .233 \\
\hline \multirow{3}{*}{$\begin{array}{c}\mathrm{TG} \\
(\mathrm{mg} / \mathrm{dL})\end{array}$} & \multirow{2}{*}{ VIAE } & \multirow{2}{*}{10} & \multirow{2}{*}{$\begin{array}{c}79.73 \\
\pm 17.43\end{array}$} & \multirow{2}{*}{$\begin{array}{c}67.83 \\
\pm 5.79\end{array}$} & Group & $.019^{*}$ \\
\hline & & & & & Time & $.008^{*}$ \\
\hline & $\underset{\mathrm{E}}{\mathrm{MIA}}$ & 9 & $\begin{array}{c}69.35 \\
\pm 9.16\end{array}$ & $\begin{array}{c}58.25 \\
\pm 14.10\end{array}$ & $\begin{array}{l}\text { Group } \\
\times \text { Time }\end{array}$ & .922 \\
\hline \multirow{3}{*}{$\begin{array}{l}\text { HDL-C } \\
(\mathrm{mg} / \mathrm{dL})\end{array}$} & \multirow[t]{2}{*}{ VIAE } & \multirow[t]{2}{*}{10} & \multirow{2}{*}{$\begin{array}{r}32.06 \\
\pm 5.34\end{array}$} & \multirow{2}{*}{$\begin{array}{c}41.25 \\
\pm 13.23\end{array}$} & Group & .086 \\
\hline & & & & & Time & $.017 *$ \\
\hline & $\underset{\mathrm{E}}{\mathrm{MIA}}$ & 9 & $\begin{array}{l}38.81 \\
\pm 6.48\end{array}$ & $\begin{array}{c}46.11 \\
\pm 12.78\end{array}$ & $\begin{array}{l}\text { Group } \\
\times \text { Time }\end{array}$ & .776 \\
\hline \multirow{3}{*}{$\begin{array}{l}\text { LDL-C } \\
(\mathrm{mg} / \mathrm{dL})\end{array}$} & \multirow{2}{*}{ VIAE } & \multirow{2}{*}{10} & \multirow{2}{*}{$\begin{array}{c}119.50 \\
\pm 13.96\end{array}$} & \multirow{2}{*}{$\begin{array}{r}93.75 \\
\pm 5.03\end{array}$} & Group & .751 \\
\hline & & & & & Time & .142 \\
\hline & $\begin{array}{c}\text { MIA } \\
\text { E }\end{array}$ & 9 & $\begin{array}{c}106.94 \\
\pm 13.96 \\
\end{array}$ & $\begin{array}{c}99.17 \\
\pm 10.54\end{array}$ & $\begin{array}{l}\text { Group } \\
\times \text { Time }\end{array}$ & .426 \\
\hline
\end{tabular}

VIAE: vigorous-intensive aerobic exercise, MIAE: moderate-intensive aerobic exercise, TG: triglyceride, HDL-C: high density lipoprotein cholesterol, LDL-C: low density lipoprotein cholesterol. ${ }^{*} p<.05$

결과, 그룹과 시점에서 모두 유의한 차이가 나타나지 않았 다(각각 $\mathrm{F}=.102, p=.751 ; \mathrm{F}=2.258, p=.142$ ) (Table 7).

\section{논 의}

\section{신체구성 및 운동수행능력 변화}

본 연구 결과, $\mathrm{VIAE}$ 그룹과 $\mathrm{MIAE}$ 그룹 모두에서 체 중 $(\mathrm{kg}), \mathrm{BMI}\left(\mathrm{kg} / \mathrm{m}^{2}\right)$, 체지방률 $(\%)$ 이 감소하였음을 관 찰하였다. 이는 포괄적으로 유산소성 운동 강도 차이와는 높은 상관 비례 없이 운동에 따른 신체구성에 대한 긍정 적인 효과로 볼 수 있으며, 이는 강도차이에 따른 여러 선 행 연구를 통해서도 체중과 $\mathrm{BMI}$, 체지방률의 유의한 감 소를 보고한 바 있다(Botero et al., 2014; Kelly et al., 
2014; Willis, 2012). 단, 본 연구에서는 운동 강도에 따 른 체지방률의 유의한 차이를 관찰하지 못하였다. 이는 본 연구의 8 주라는 상대적으로 적은 운동 기간 또는 적은 대상자 수에 기인하는 결과일 수 있다. 그럼에도 VIAE 그룹이 MIAE 그룹보다 수치상 신체구성의 모든 요인들 이 더욱 감소함을 확인하였는데 이러한 결과를 토대로, 유산소성 운동 수행을 함에 신체적인 장애가 없다면 중등 강도 이상 높은 강도를 실시하는 것이 더욱 효과적일 수 있을 것으로 생각된다(Khoo et al., 2013).

한편, 본 연구에서 두 운동 그룹 간 유산소성수행능력 즉 최대산소섭취량은 그룹과 시점 간 상호작용 효과를 확 인함으로써 VIAE 그룹이 MIAE보다 유의하게 높음을 관 찰하였다. 규칙적인 유산소성 운동은 보편적으로 최대산 소섭취량 증가에 이점을 제공한다(Bernhardt et al., 2016; Conraads et al., 2014; Sijie et al., 2012). Gormley et al. (2008)은 성인을 대상으로 주 4회 60분 가량 강도별 유산소성 운동(moderate: $\mathrm{VO}_{2} 50 \%$, vigorous: $\mathrm{VO}_{2} 75 \%$, maximal: $\mathrm{VO}_{2} 95 \%$ )을 한 결과, 그룹별 약 $10 \%$, 약 $14.3 \%$, 약 $20.6 \%$ 최대산소섭취량이 증가하였음을 보고하며, 유산소성 운동 강도에 따라 최대 산소섭취량의 증가가 비례함을 입증한 바 있다. 최대산소 섭취량 증가에 대한 규칙적인 유산소 운동의 효과는 심폐 기능 적응과 골격근 내 mitochondria 크기와 수의 증가, 그리고 근육 내 glycogen 저장량 능력 향상, 그리고 Krebs cycle과 호흡 연계에 의한 대사 활동의 증가에 의 한 결과라고 사료된다(Aoike et al., 2015; Dandanell et al., 2017; Yoon et al., 2017). 본 연구에서 적용한 $\mathrm{VIAE}$ 그룹의 운동 강도가 MIAE 그룹보다 신체 내 대사 적 응을 더욱 유도하며, 보다 강한 운동 강도로 인해 심폐 기능 과 골격근에서의 mitochondria 크기와 수 증가 등 더욱 향 상할 수 있기에 최대산소섭취량의 선형적인 증가 현상은 $\mathrm{MIAE}$ 그룹보다 VIAE 그룹에서 나타난 것으로 생각된다.

\section{혈중 BDNF 농도 및 노화 관련 호르몬의 변화}

본 연구 결과, 혈중 $\mathrm{BDNF}$ 농도는 그룹과 시점 간 상호 작용 효과를 확인함으로써 $\mathrm{VIAE}$ 그룹이 MIAE보다 유의 하게 높음을 관찰하였다. 선행연구들에서는 고강도 유산 소성 운동이 중등강도와 비교하여 혈중 $\mathrm{BDNF}$ 농도의 증
가에 효과적임을 보고한 바 있다(Afzalpour et al., 2015; Ross et al., 2019; TaheriChadorneshin et al., 2017).

특히, 운동 시 $\mathrm{BDNF}$ 는 신경조직, 골격근 등에서 발현되 며(Matthews et al., 2009), 학습과 기억에 중요한 역할 을 한다고 보고되며(Aguiar et al., 2011; Araki et al., 2014; Corripio et al., 2012; Cowansage et al., 2010), 혈중 $\mathrm{BDNF}$ 농도의 증가가 혈당, 유리지방산, 총콜 레스테롤과 같은 생활습관병 관련 혈액 변인의 개선과 밀접 한 관련이 있다고 보고한 바 있다(Tsuchida et al., 2002; Tsuchida et al., 2001).

게다가, 대부분의 선행연구에서는 유산소 운동 후 혈 중 BDNF가 증가하며(Rushcheweyh et al., 2011), 이 는 운동강도와 비례하며, 강도 차이에 따라 의존 될 수 있 다고 주장하였다(Rojas Vega et al., 2012).

이러한 주장은 혈중 $\mathrm{BDNF}$ 농도가 운동 강도와 밀접한 관련성이 있음을 입증하는 부분이고, 이는 본 연구와 일치 하는 결과이며, 나아가 혈중 $\mathrm{BDNF}$ 는 중등강도 보다는 고강도의 유산소성 운동이 혈중 $\mathrm{BDNF}$ 의 발현에 더욱 반 응하기에 고강도의 운동이 효과적인 것으로 사료된다.

이로 말미암아 고강도 유산소성 운동이 중등강도보다 중 년 여성의 혈중 $\mathrm{BDNF}$ 농도를 증가함으로써 학습 및 기억 능 력 개선뿐만 아니라 생활습관병 관련 혈액 변인의 개선에도 긍정적인 영향을 미칠 수 있을 것으로 판단된다.

다만, 본 연구에서는 혈액 변인만 검증하였기에, 학습 및 기억 능력 개선 효과를 규명하지 못한 제한점이 있다. 이러한 효과를 명확히 규명하기 위하여 추후 유산소성 운동 강도에 따른 혈중 $\mathrm{BDNF}$ 농도와 학습, 기억 및 인지 능력을 측정할 필요가 있을 것으로 생각된다.

아울러, 본 연구에서는 유산소성 운동 강도에 따른 노 화 관련 호르몬의 변화를 살펴보기 위해 혈중 $\mathrm{DHEA}-\mathrm{S}$ 와 $\mathrm{IGF}-1$ 농도의 변화를 검증하고자 하였으며, 그 결과, 혈 중 DHEA-S와 IGF-1 농도는 두 그룹 모두 사전과 비교 하여 사후에 유의하게 증가함을 관찰하였다. 선행연구에 서는 12 주간 유산소성 운동을 통해 DHEA-s 농도를 증가하 였다고 보고한 바 있다(Di Blasio et al., 2017; Izzicupo et al., 2013). 본 연구에서는 운동량을 동일하게 적용하고 자 하였으며, 그 결과, 두 그룹 모두 혈중 DHEA-s 농도를 증가하였는데 이를 비추어볼 때 혈중 $\mathrm{DHEA}-\mathrm{S}$ 농도를 변 
화시키기 위해서는 운동 강도보다 운동량이 중요한 역할 을 할 것으로 생각된다. 또한, IGF-1과 관련하여 선행연구 에서는 고강도 및 저강도 운동에 의해 혈중 $\mathrm{IGF}-1$ 농도가 모 두 증가하였으며(Schwarz et al., 1996), Walsh et al. (2015)는 유산소성 운동이 IGF-1과 BDNF 증가에 효과적 임을 확인한 바 있다. 다른 선행연구에서는 혈중 IGF-1 농도 가 유산소성 운동뿐만 아니라 운동의 형태와 관계없이 유의 하게 증가한다고 보고하였다(Zoladz et al., 2008). 본 연 구 결과, IGF-1 농도는 두 그룹 모두 사전보다 사후 유의 하게 증가하였는데 이러한 결과는 선행연구의 결과와 유 사한 결과이다(Kennedy et al., 2016; Walsh et al., 2015). McCusker et al. (2006)은 뇌에서 IGF-1과 BDNF 가 신경세포 생존과 가소성을 향상하기 위해 활동하며, IGF-1 증가에 의해 $\mathrm{BDNF}$ 도 증가한다고 보고하여 $\mathrm{IGF}-1$ 과 인지기능 과 관련이 있음을 확인한 바 있는데(Aleman et al., 1999) 본 연구결과를 토대로 살펴볼 때, 혈중 IGF-1 농도는 운동 강 도 및 형태에 독립적으로 증가할 수 있으며, $\mathrm{BDNF}$ 와 연 관은 있지만, 직접적인 연관성은 다소 낮음을 확인할 수 있었다. 중요한 것은 규칙적인 유산소성 운동에 의해 운 동 강도와 상관없이, 혈중 DHEA-s, IGF-1 농도를 모두 증가하였다는 것은 주목할 만한 결과이다. 즉 고강도 및 중 등강도 유산소성 운동은 중년 여성의 혈중 DHEA-s와 IGF-1 농도에 긍정적인 영향을 미침으로써 노화를 지연할 수 있을 것으로 생각된다.

\section{생활습관병 관련 혈액 변인의 변화}

일반적으로 운동은 여러 가지 건강상의 이점을 제공하 기에, 건강 유지 및 관리를 위한 치료적인 생활습관의 변 화를 위해 추천된다(Kannan et al., 2014). 특히, 다수 선행연구에서 규칙적인 운동으로 인한 체지방률의 긍정 적인 변화가 궁극적으로 동맥경화성 혈관 질환 등의 조기 발병 예방에 기여할 수 있으며, 지방 산화를 통한 비만 개 선 등 신체 내 건강상의 이점을 보고하고 있기에(Jordy et al., 2015; Park et al., 2010; Pesta et al., 2017), 규칙적인 운동의 필요성은 한층 더 강조되고 있다.

이와 관련하여 본 연구에서는 유산소성 운동 강도에 따른 생활습관병 관련 혈액 변인의 변화를 검증하고자 하 였으며, 그 결과, 혈중 글루코스 농도는 상호작용 효과와
그룹과 시점에 대한 주효과가 관찰되지 않았다. 통계적인 유의함은 관찰되지 않았으나 VIAE 그룹에서 사전과 비교 하여 사후에 수치상 감소하는 경향을 확인하였다. 이러한 이유로는 사전 검사 시 두 그룹 모두 정상 범위 내에 있어 운동을 통한 생리적 변화의 여지가 적었기 때문으로 사료 된다. 그러나 비록 통계적으로 유의한 차이는 나타나진 않았으나 혈중 글루코스 농도의 감소 결과는 보편적인 운 동 효과로 골격근의 myoglobin의 증가와 mitochondria 수와 크기 증가 그리고 유산소성수행능력 향상과 더불어 근 육에서의 glycogen 이용률 감소, 지방 산화 증가에 기인한다 고 생각된다(Carrera-Quintanar et al., 2017; Cayla et al., 2008).

혈중 유리지방산 농도의 결과를 살펴보면, 혈중 유리 지방산 농도는 두 그룹 모두 사전보다 사후에 유의하게 감소함을 관찰하였다. 이는 규칙적인 운동을 통해 글루코 스와 유리지방산 농도를 감소함으로써 여러 가지 생활습 관병 위험 요인들을 개선할 수 있음을 의미한다. 특히, 규 칙적인 운동 적용 이후 기간의 경과에 따라 인체 내에서 는 애당초 적용한 운동 강도보다 더욱 낮은 강도로 받아 들이는 탓에, 상대적으로 지방 산화에 의한 에너지 생성 에 의존하게 되고 이에 따라 탄수화물보다 지방을 더 많 이 사용하였을 가능성이 있다. Kannan et al. (2014)의 강도별 운동을 한 결과, 중등강도 그룹에서는 유의한 변 화가 없었고 고강도 그룹에서 중성지방, $\mathrm{LDL}-\mathrm{C}$ 의 감소 를 관찰한 바 있다. 또한, 운동 강도에 따른 또 다른 선행 연구들에서는 운동 강도와 혈중 지질의 개선이 비례하는 경향을 일관되게 보고하고 있는데(Marandi et al., 2013; Ouerghi et al., 2014) 이는 본 연구 결과에서 $\mathrm{LDL}-\mathrm{C}$ 의 통계적인 유의함을 확인하지 못하였으나 본 연 구의 수치상 결과 변화와 유사함을 보인다. 본 연구는 선 행연구들과 비교하여 상대적으로 8주라는 짧은 운동 기 간이며, 연구대상자 수도 상대적으로 적은 편에 속한다. 추후 더욱 긴 기간의 운동과 함께 더욱 많은 연구대상자 를 모집함으로써 유산소성 운동 강도에 따른 혈중 글루코 스 및 유리지방산, 중성지방 등의 농도 변화를 명확히 검 증할 필요가 있을 것으로 생각된다.

또한, 본 연구에서 유산소성 운동 강도에 따른 혈중 $\mathrm{HDL}-\mathrm{C}$ 농도의 변화를 검증한 결과, 두 그룹 사전보다 사 후에 유의하게 증가함을 관찰하였다. 그리고 혈중 
$\mathrm{LDL}-\mathrm{C}$ 농도는 두 그룹 모두 수치상 감소하는 경향을 나 타냈으나 통계적인 유의함은 나타나지 않았다. 결과적으 로 $\mathrm{HDL}-\mathrm{C}$ 와 $\mathrm{LDL}-\mathrm{C}$ 농도는 $\mathrm{VIAE}$ 그룹이 $\mathrm{MIAE}$ 그룹 보다 수치상 긍정적인 변화가 관찰되었다. 선행연구에서 는 유산소성 운동이 지단백 분해효소인 lipoprotein lipase의 활성을 증가함으로써 중성지방 농도 감소를 촉 진하고 $\mathrm{HDL}-\mathrm{C}$ 농도를 증가하였다고 보고한바 있다 (Mezghanni et al., 2012; Narayani \& Sudhan, 2010). 또한, 선행연구에 따르면, TC 또는 LDL-C 농도 가 $1 \%$ 감소하면 관상동맥 질환 위험성이 $2 \%$ 감소하고, $\mathrm{HDL}-\mathrm{C}$ 수치가 $1 \%$ 감소하면 관상동맥 심장질환 위험성 이 2 3\%가 증가함을 시사하고 있다(Gordon et al., 1989; Ouerghi et al., 2014; Pedersen et al., 1998). 이에, 고강도 유산소성 운동과 중등강도 유산소성 운동은 $\mathrm{HDL}-\mathrm{C}$ 과 $\mathrm{LDL}-\mathrm{C}$ 농도에 긍정적인 변화를 유도하며, 특 히 수치상 변화로 말미암아 고강도 유산소성 운동이 $\mathrm{HDL}-\mathrm{C}$ 과 $\mathrm{LDL}-\mathrm{C}$ 농도에 더욱 긍정적인 변화를 유도할 수 있음을 확인하였다.

\section{결론 및 제언}

본 연구의 목적은 8 주간 유산소성 운동 강도가 중년 여 성의 신체구성, 유산소성수행능력, 혈중 $\mathrm{BDNF}$ 및 노화 관련 호르몬 그리고 생활습관병 관련 혈액 변인에 미치는 영향을 규명하고자 하였다. 본 연구에서 얻은 결과를 요 약하여, 기술하면 다음과 같다.

1. 평균 운동 시간은 VIAE 그룹보다 MIAE 그룹이 유 의하게 더욱 길었다(Table 3). 최대산소섭취량은 두 그룹 모두 증가하였으며, VIAE 그룹이 MIAE보 다 유의하게 높음을 관찰하였다(Table 4).

2. 체중, BMI, 체지방률의 경우, 두 그룹 모두 유의하 게 감소하였다(Table 5).

3. 혈중 $\mathrm{BDNF}$ 농도는 두 그룹 모두 증가하였으며, $\mathrm{VIAE}$ 그룹이 MIAE보다 유의하게 높음을 관찰하였 다. 또한, 노화 관련 호르몬 변화의 경우, $\mathrm{DHEA}-\mathrm{S}$ 와 IGF- 1 농도는 두 그룹 모두 사전과 비교하여 사 후에 유의하게 증가함을 관찰하였다(Table 6).
4. 생활습관병 관련 혈액 변인의 경우, 유리지방산, 중 성지방 농도는 두 그룹 모두 사전보다 사후에 유의 하게 감소하였다. 또한, $\mathrm{HDL}-\mathrm{C}$ 농도는 두 그룹 모두 사전보다 사후에 유의하게 증가하였다(Table 7).

이상의 결과를 종합해보면 8주간 고강도 유산소성 운 동은 중년 여성의 최대산소섭취량, 혈중 $\mathrm{BDNF}$ 농도를 더욱 증가할 뿐만 아니라 노화 관련 호르몬, 생활습관병 관련 혈액 변인의 긍정적인 변화를 유도할 수 있음을 입 증하였다. 이에, 생활습관병 개선 및 신체구성 개선에 대 한 이점만을 위해 운동하고자 한다면 중등강도 운동만 하 여도 무방할 것으로 생각된다. 하지만 추가적으로 혈중 $\mathrm{BDNF}$ 의 농도와 노화 관련 호르몬 등 그리고 유산소성수 행능력의 이점까지 도모하고자 한다면 고강도 유산소성 운동을 규칙적으로 하는 것이 바람직할 것으로 생각된다.

본 연구에서는 중년 여성을 대상으로 폐경 및 월경 주 기를 통제하고 운동량을 동일화하고자 하였으나 운동 기 간이 짧고 연구대상자 수가 다소 적은 제한점이 있다. 이 에 더욱 명확한 효과 검증을 위해 추후 연구에서는 많은 연구대상자와 함께 더욱 긴 기간의 운동을 적용할 필요가 있을 것으로 생각된다.

\section{참고문헌}

Korea statistics. (2019). Population projection.

American College of Sports Medicine, Riebe, D., Ehrman, J. K., Liguori, G., \& Magal, M. (2018). ACSM's guidelines for exercise testing and prescription(10th ed.). Wolters Kluwer.

Aoike, D. T., Baria, F., Kamimura, M. A., Ammirati, A., de Mello, M. T., \& Cuppari, L. (2015). Impact of home-based aerobic exercise on the physical capacity of overweight patients with chronic kidney disease. International urology and nephrology, 47(2), 359-367.

Ainsworth, B. E., Haskell, W. L., Whitt, M. C., Irwin, M. L., Swartz, A. M., Strath, S. J., ... \& Jacobs, D. R. (2000). Compendium of physical activities: an update of activity codes and MET intensities. Medicine and science in sports and exercise, 32(9; SUPP/1), S498-S504.

Afzalpour, M. E., Chadorneshin, H. T., Foadoddini, M., \& Eivari, 
H. A. (2015). Comparing interval and continuous exercise training regimens on neurotrophic factors in rat brain. Physiology \& behavior, 147, 78-83.

Aguiar Jr, A. S., Castro, A. A., Moreira, E. L., Glaser, V., Santos, A. R., Tasca, C. I., \& Prediger, R. D. (2011). Short bouts of mild-intensity physical exercise improve spatial learning and memory in aging rats: involvement of hippocampal plasticity via AKT, CREB and BDNF signaling. Mechanisms of ageing and development, 132(11-12), 560-567.

Aleman, A., Verhaar, H. J., de Haan, E. H., de Vries, W. R., Samson, M. M., Drent, M. L., ... \& Koppeschaar, H. P. (1999). Insulin-like growth factor-I and cognitive function in healthy older men. The Journal of Clinical Endocrinology \& Metabolism, 84(2), 471-475.

Angelucci, F., Piermaria, J., Gelfo, F., Shofany, J., Tramontano, M., Fiore, M., ... \& Peppe, A. (2016). The effects of motor rehabilitation training on clinical symptoms and serum BDNF levels in Parkinson's disease subjects. Canadian Journal of Physiology and Pharmacology, 94(4), 455-461.

Araki, S., Yamamoto, Y., Dobashi, K., Asayama, K., \& Kusuhara,

K. (2014). Decreased plasma levels of brain-derived neurotrophic factor and its relationship with obesity and birth weight in obese Japanese children. Obesity Research and Clinical Practice, 8(1), e63-69.

Bergeron, J., Couillard, C., Després, J. P., Gagnon, J., Leon, A. S., Rao, D. C., ... \& Bouchard, C. (2001). Race differences in the response of postheparin plasma lipoprotein lipase and hepatic lipase activities to endurance exercise training in men: results from the HERITAGE Family Study. Atherosclerosis, 159(2), 399-406.

Bernhardt, V., Stickford, J. L., Bhammar, D. M., \& Babb, T. G. (2016). Aerobic exercise training without weight loss reduces dyspnea on exertion in obese women. Respiratory physiology \& neurobiology, 221, 64-70.

Bisdee, J. T., Garlick, P. J., \& James, W. P. T. (1989). Metabolic changes during the menstrual cycle. British journal of nutrition, 61(3), 641-650.

Botero, J. P., Prado, W. L., Guerra, R. L., Speretta, G. F., Leite, R. D., Prestes, J., ... \& Perez, S. E. (2014). Does aerobic exercise intensity affect health related parameters in overweight women?. Clinical physiology and functional imaging, 34(2), 138-142.

Carrera-Quintanar, L., Funes, L., Sánchez-Martos, M.,
Martinez-Peinado, P., Sempere, J. M., Pons, A., ... \& Roche, E. (2017). Effect of a 2000-m running test on antioxidant and cytokine response in plasma and circulating cells. Journal of physiology and biochemistry, 73(4), 523-530.

Cayla, J. L., Maire, P., Duvallet, A., \& Wahrmann, J. P. (2008). Erythropoietin induces a shift of muscle phenotype from fast glycolytic to slow oxidative. International journal of sports medicine, 29(06), 460-465.

Colcombe, S. J., Erickson, K. I., Raz, N., Webb, A. G., Cohen, N. J., McAuley, E., \& Kramer, A. F. (2003). Aerobic fitness reduces brain tissue loss in aging humans. The Journals of Gerontology Series A: Biological Sciences and Medical Sciences, 58(2), M176-M180.

Conraads, V. M., Pattyn, N., De Maeyer, C., Beckers, P. J., Coeckelberghs, E., Cornelissen, V. A., ... \& Possemiers, N. (2015). Aerobic interval training and continuous training equally improve aerobic exercise capacity in patients with coronary artery disease: the SAINTEX-CAD study. International journal of cardiology, 179, 203-210.

Corpas, E., Harman, S. M., \& Blackman, M. R. (1993). Human growth hormone and human aging. Endocrine reviews, 14(1), 20-39.

Corripio, R., Gonzalez-Clemente, J. M., Perez-Sanchez, J., Naf, S., Gallart, L., Vendrell, J., et al. (2012). Plasma brain-derived neurotrophic factor in prepubertal obese children: results from a 2-year lifestyle intervention programme. Clinical Endocrinology, 77, 715-720.

Cowansage, K. K., LeDoux, J. E., \& Monfils, M. H. (2010). Brain-derived neurotrophic factor: a dynamic gatekeeper of neural plasticity. Current molecular pharmacology, 3(1), 12-29.

Dandanell, S., Elbe, A. M., Pfister, G., Elsborg, P., \& W Helge, J. (2017). Relationship between volition, physical activity and weight loss maintenance: study rationale, design, methods and baseline characteristics. Scandinavian journal of public health, 45(3), 299-304.

Di Blasio, A., Morano, T., Cianchetti, E., Gallina, S., Bucci, I., Di Santo, S., ... \& Cimini, A. (2017). Psychophysical health status of breast cancer survivors and effects of 12 weeks of aerobic training. Complementary therapies in clinical practice, 27 , 19-26.

Dimeo, F., Bauer, M., Varahram, I., Proest, G., \& Halter, U. (2001). Benefits from aerobic exercise in patients with major 
depression: a pilot study. British journal of sports medicine, 35(2), 114-117.

Ferris, L. T., Williams, J. S., \& Shen, C. L. (2007). The effect of acute exercise on serum brain-derived neurotrophic factor levels and cognitive function. Medicine and science in sports and exercise, 39(4), 728

Franks, D., \& Howley, E. T. (1998). Health Fitness Instructor's Handbook(3rd ed). Human Kinetics.

Gauchard, G. C., Gangloff, P., Jeandel, C., \& Perrin, P. P. (2003). Influence of regular proprioceptive and bioenergetic physical activities on balance control in elderly women. The Journals of Gerontology Series A: Biological Sciences and Medical Sciences, 58(9), M846-M850.

Gordon, D. J., Probstfield, J. L., Garrison, R. J., Neaton, J. D., Castelli, W. P., Knoke, J. D., ... \& Tyroler, H. A. (1989). High-density lipoprotein cholesterol and cardiovascular disease. Four prospective American studies. Circulation, 79(1), 8-15.

Gormley, S. E., Swain, D. P., High, R. E. N. E. E., Spina, R. J., Dowling, E. A., Kotipalli, U. S., \& Gandrakota, R. A. M. Y. A. (2008). Effect of intensity of aerobic training on $\mathrm{VO}_{2} \max$. Medicine \& Science in Sports \& Exercise, 40(7), 1336-1343.

Ha, M. S., \& Son, W. M. (2018). Combined exercise is a modality for improving insulin resistance and aging-related hormone biomarkers in elderly Korean women. Experimental Gerontology, 114, 13-18.

Izzicupo, P., D’Amico, M. A., Bascelli, A., Di Fonso, A., D’Angelo, E., Di Blasio, A., ... \& Di Baldassarre, A. (2013). Walking training affects dehydroepiandrosterone sulfate and inflammation independent of changes in spontaneous physical activity. Menopause, 20(4), 455-463.

Jeon, Y. K., \& Ha, C. H. (2017). The effect of exercise intensity on brain derived neurotrophic factor and memory in adolescents. Environmental health and preventive medicine, 22(1), 27.

Jordy, A. B., Kraakman, M. J., Gardner, T., Estevez, E., Kammoun, H. L., Weir, J. M., ... \& Henstridge, D. C. (2015). Analysis of the liver lipidome reveals insights into the protective effect of exercise on high-fat diet-induced hepatosteatosis in mice. American Journal of Physiology-Endocrinology and Metabolism, 308(9), E778-E791.

Kannan, U., Vasudevan, K., Balasubramaniam, K., Yerrabelli, D., Shanmugavel, K., \& John, N. A. (2014). Effect of exercise intensity on lipid profile in sedentary obese adults. Journal of clinical and diagnostic research, 8(7), BC08.

Kelly, K. R., Navaneethan, S. D., Solomon, T. P., Haus, J. M., Cook, M., Barkoukis, H., Kirwan, J. P. (2014). Lifestyle-induced decrease in fat mass improves adiponectin secretion in obese adults. Medicine and science in sports and exercise, 46(5):920-6.

Kennedy, G., Hardman, R.J., Macpherson, H., Scholey, A.B., Pigingas, A. (2016). How Does Exercise Reduce the Rate of Age-Associated Cognitive Decline? A Review of Potential Mechanisms. J Alzheimers Dis. 55(1), 1-18.

Khoo, J., Tian, H.H., Tan, B., Chew, K., NG, C.S., Leong, D., Teo, R.C., Chen, R.Y. (2013). Comparing effects of low- and hihg-volume moderate-intensity exercise on sexual function and testosterone in obese men. The Journal of Sexual Medicine, 10(7), 1823-1832.

Mackay, C. P., Kuys, S. S., \& Brauer, S. G. (2017). The effect of aerobic exercise on brain-derived neurotrophic factor in people with neurological disorders: a systematic review and meta-analysis. Neural plasticity, 2017.

Marandi, S. M., Abadi, N. G. B., Esfarjani, F., Mojtahedi, H., \& Ghasemi, G. (2013). Effects of intensity of aerobics on body composition and blood lipid profile in obese/overweight females. International journal of preventive medicine, 4(Suppl 1), S118.

Mezghanni, N., Chaabouni, K., Chtourou, H., Masmoudi, L., Chamari, K., Lassoued, A., ... \& Mejdoub, H. (2012). Effect of exercise training intensity on body composition, lipid profile, and insulin resistance in young obese women. African Journal of Microbiology Research, 6(10), 2481-2488.

McArdle, W. D., Katch, F. I., \& Katch, V. L. (2010). Exercise physiology: nutrition, energy, and human performance. Lippincott Williams \& Wilkins.

McCusker, R. H., McCrea, K., Zunich, S., Dantzer, R., Broussard, S. R., Johnson, R. W., \& Kelley, K. W. (2006). Insulin-like growth factor-I enhances the biological activity of brain-derived neurotrophic factor on cerebrocortical neurons. Journal of neuroimmunology, 179(1-2), 186-190.

Matthews, V., Åström, M. B., Chan, M. H. S., Bruce, C. R., Krabbe, K. S., Prelovsek, O., \& Penkowa, M. (2009). Brain-derived neurotrophic factor is produced by skeletal muscle cells in response to contraction and enhances fat oxidation via activation of AMP-activated protein kinase. Diabetologia, 52(7), 1409-1418. 
Narayani, U., \& Sudhan, P. R. (2010). Effect of aerobic training on percentage of body fat, total cholesterol and HDL-C among obese women. World Journal of Sport Sciences, 3(1), 33-36.

Norton, K., Norton, L., \& Sadgrove, D. (2010). Position statement on physical activity and exercise intensity terminology. Journal of science and medicine in sport, 13(5), 496-502.

Ouerghi, N., Khammassi, M., Boukorraa, S., Feki, M., Kaabachi, N., \& Bouassida, A. (2014). Effects of a high-intensity intermittent training program on aerobic capacity and lipid profile in trained subjects. Journal of sports medicine, 5, 243.

Park, S. K., Kwon, Y. C., Kim, E. H. and Park, J. K. (2010). Effect of combined exercise training on carotid artery peak-systolic flow velocity and erachial artery flow-mediated dilation in obese middle aged men. Journal of Sport and Leisure Studies, 39, 673-682.

Pedersen, T. R., Olsson, A. G., Færgeman, O., Kjekshus, J., Wedel, H., Berg, K., ... \& Miettinen, T. (1998). Lipoprotein changes and reduction in the incidence of major coronary heart disease events in the Scandinavian Simvastatin Survival Study(4S). Circulation, 97(15), 1453-1460.

Pesta, D. H., Goncalves, R. L., Madiraju, A. K., Strasser, B., \& Sparks, L. M. (2017). Resistance training to improve type 2 diabetes: working toward a prescription for the future. Nutrition \& metabolism, 14(1), 24.

Ross, R. E., Saladin, M. E., George, M. S., \& Gregory, C. M. (2019). High-Intensity Aerobic Exercise Acutely Increases Brain-derived Neurotrophic Factor. Medicine and science in sports and exercise, 51(8), 1698-1709.

Rojas Vega, S., Hollmann, W., Wahrmann, V., \& Strüder, H. K. (2012). pH buffering does not influence BDNF responses to exercise. International Journal of Sports Medicine, 33(1), 8-12.

Ruscheweyh, R., Willemer, C., Krüger, K., Duning, T., Warnecke, T., Sommer, J., Volker, K, Ho, H. V., Mooren, F., Knecht, S., \& Flöel, A. (2011). Physical activity and memory functions: an interventional study. Neurobiology of aging, 32(7), 1304-1319.

Schmolesky, M. T., Webb, D. L., \& Hansen, R. A. (2013). The Effects of Aerobic Exercise Intensity and Duration on Levels of Brain Derived Neurotrophic Factor in Healthy Men. Journal of Sports Science and Medicin, 12, 502-511.

Sijie, T., Hainai, Y., Fengying, Y., \& Jianxiong, W. (2012). High intensity interval exercise training in overweight young women. The Journal of sports medicine and physical fitness, 52(3), 255-262.

TaheriChadorneshin, H., Cheragh-Birjandi, S., Ramezani, S., \& Abtahi-Eivary, S. H. (2017). Comparing sprint and endurance training on anxiety, depression and its relation with brain-derived neurotrophic factor in rats. Behavioural brain research, 329, 1-5.

Thoms, G., Frenoy, N., Legrain, S., Sebag-Lanone, R., Baulieu, E. E., \& Debuire, B. (1994). Serum deyhydroepiandrosterone sulfate levels as an individual marker. Journal of clinical endocrinology and metabolism, 79(5), 1273-1276.

Tsuchida, A., Nonomura, T., Nakagawa, T., Itakura, Y., Ono Kishino, M., Yamanaka, M., ... \& Noguchi, H. (2002). Brain derived neurotrophic factor ameliorates lipid metabolism in diabetic mice. Diabetes, obesity and metabolism, 4(4), 262-269.

Tsuchida, A., Nonomura, T., Ono-Kishino, M., Nakagawa, T., Taiji, M., \& Noguchi, H. (2001). Acute effects of brain-derived neurotrophic factor on energy expenditure in obese diabetic mice. International journal of obesity, 25(9), 1286.

Schwarz, A. J., Brasel, J. A., Hintz, R. L., Mohan, S. \& Cooper, D. M.(1996). Acute effect of brief low- and high-intensity exercise on circulating insulin-like growth factor (IGF)I, I I, a nd I GF-b niding p rotein-3 and its proteolysis in young healthy men. The Journal of Clinical Endocrinology and Metabolis, 81(10), 3492-3497.

Vega, S. R., Strüder, H. K., Wahrmann, B. V., Schmidt, A., Bloch, W., \& Hollmann, W. (2006). Acute BDNF and cortisol response to low intensity exercise and following ramp incremental exercise to exhaustion in humans. Brain research, 1121(1), 59-65.

Walsh JJ, Edgett BA, Tschakovsky ME, Gurd BJ. (2015). Fasting and exercise differentially regulate BDNF mRNA expression in human skeletal muscle. Applied Physiology, Nutrition, and Metabolism, 40(1), 96-98.

Willis, L.H., Slentz, C.A., Bateman, L.A., Shields, A.T., Piner, L.W., Bales, C.W., Houmard, J.A., Kraus, W.E. (2012). Effects of aerobic and/or resistance training on body mass and fat mass in overweight or obese adults. Journal of Applied Physiology, 113(12), 1831-1837.

Yoon, J. G., Kim, S. H., \& Rhyu, H. S. (2017). Effects of 16-week spinning and bicycle exercise on body composition, physical fitness and blood variables of middle school students. Journal 
of exercise rehabilitation, 13(4), 400.

Zoladz, J. A., Pilc, A., Majerczak, J., Grandys, M., Zapart-Bukowska, J., \& Duda, K. (2008). Endurance training increases plasma brain-derived neurotrophic factor concentration in young healthy men. Journal of Physiology and Pharmacology, 59(Suppl 7), 119-132.

\title{
고강도와 중등강도 유산소성 운동이 중년 여성의 혈중 $\mathrm{BDNF}$ 농도, 노화 관련 호르몬 및 생활습관병 관련 혈액 변인에 미치는 영향
}

\author{
고재면 ${ }^{1}$, 안지영 ${ }^{2}$, 이진석 ${ }^{3}$ \\ ${ }^{1}$ 연세대학교 박사 \\ 2고려대학교 박사 \\ 3한국스포츠정책과학원 연구위원
}

[목적] 본 연구는 8주간 고강도와 중등강도 유산소성 운동이 중년 여성의 혈중 $\mathrm{BDNF}$ 농도 및 노화 관련 호르몬, 생활습관병 관련 혈액 변인, 그리고 신체구성, 유산소성수행능력에 미치는 영향을 규명하고자 하였다. 〔방법〕 연구대상자는 신체적으로 건강한 50 대 여성 총 19 명을 대상으로 하였으며, 연구대상자들은 고강도 유산소성 운동 그룹(VIAE, $\mathrm{n}=10$ )과 중등강도 유산소성 운동 그룹(MIAE, $\mathrm{n}=9$ )으로 무작위 분류하였다. 유산소성 운동은 8주간 주 3회 트레드밀 달리기 형태로 실시하였으며, 운동부하검사를 통해 $\mathrm{VO}_{2} \max$ 를 기준 으로 고강도 운동 그룹(VIAE)은 $\mathrm{VO}_{2} \max$ 의 $75 \sim 80 \%$ 강도, 중등강도 운동 그룹(MIAE)은 $\dot{\mathrm{VO}}_{2} \max$ 의 $55 \sim 60 \%$ 강도에 해당하는 운동 강도 및 운동 시간을 적용하였다. 유산소성 강도에 따른 효과를 규명하기 위 하여 사전·사후 연구대상자들의 혈액 샘플을 채취하고 혈중 $\mathrm{BDNF}$ 농도 및 노화 관련 호르몬 그리고 생활습 관병 관련 혈액을 분석하였으며, 신체구성 및 유산소성 수행능력을 측정하였다. 〔결과〕 첫째, 최대산소섭취량 $\left(\mathrm{VO}_{2} \max \right)$ 은 VIAE 그룹이 MIAE 그룹보다 사후에 더욱 유의하게 증가하였다( $\left.p<.05\right)$ (Table 4). 둘째, 신 체구성의 경우 체중 $(\mathrm{kg}), \mathrm{BMI}$, 체지방률 $(\%)$ 이 두 그룹 모두 사전보다 사후에 유의하게 감소하였다 ( $p$ 〈.05) (Table 5). 셋째, 혈중 BDNF 농도는 VIAE 그룹이 MIAE 그룹보다 사후에 더욱 유의하게 증가하 였다 $(p<.05)$. 그리고 혈중 DHEA-s와 IGF-1 농도는 두 그룹 모두 사전보다 사후에 유의하게 증가하였다 ( $p$ 〈.05)(Table 6). 넷째, 혈중 FFA, TG 농도는 두 그룹 모두 사전보다 사후에 유의하게 감소하였고 ( $p<.05), \mathrm{HDL}-\mathrm{C}$ 농도는 두 그룹 모두 사전보다 사후에 유의하게 증가하였다( $p<.05$ ) (Table 7). [결론) 8 주간 고강도 유산소성 운동은 중등강도와 비교하여 중년 여성의 최대산소섭취량 $\left(\mathrm{VO}_{2} \mathrm{max}\right)$, 혈중 $\mathrm{BDNF}$ 농 도를 더욱 증가할 뿐만 아니라 노화 관련 호르몬 및 생활습관병 관련 혈액 인자의 긍정적인 변화를 유도할 수 있음을 시사한다.

주요어: 유산소성 운동, $\mathrm{BDNF}$, 노화관련 호르몬, 생활습관병 관련 혈액 변인 